\title{
The fish community as an indicator of biotic integrity of the streams in the Sinos River basin, Brazil
}

\author{
Costa, PF.* and Schulz, UH.* \\ Laboratório de Ecologia de Peixes, Universidade do Vale do Rio dos Sinos - UNISINOS, \\ Av. UNISINOS, 950, Centro de Ciências da Saúde, CEP 93022-000, São Leopoldo, RS, Brazil \\ *e-mail: patybiologia@gmail.com,uwe@unisinos.br \\ Received February 21, 2010 - Accepted April 29, 2010 - Distributed December 31, 2010
}

(With 5 figures)

\begin{abstract}
The basin of the Sinos River, located in the northeastern part of Rio Grande do Sul state, Brazil, has been highly impacted by industrial and urban activities. Water quality is low because of domestic and industrial sewage discharges. Most of the tributaries have suffered drastic structural interventions like canalisations and the removal of riparian vegetation. The aims of this study were to: 1) assess the diversity of fish at 34 sampling sites in twenty-four tributaries of the Sinos River basin; 2) quantify impact level by the Shannon-Wiener diversity index and an adapted Index of Biotic Integrity (IBI); and 3) check the interference of environmental impacts, formerly quantified in a Stream Corridor Assessment Survey (SCAS), on the fish assembly and 4) compare the relationship between the IBI with stream order. Fish sampling was performed by electric fishing in the period from April 2004 to August 2006. A total of 4,869 individuals were sampled, representing 61 species, 14 families and six orders. Significant relationships of the Shannon-Wiener index and IBI with SCAS scores and stream orders were found. Of all impacts that make up the SCAS score, only channel modifications were significantly correlated with IBI. These results indicate that the adaptation of the IBI was effective and performed better than the Shannon-Wiener diversity index when related directly to specific impact categories. The application of the IBI with the SCAS and the other variables was efficient in the tributaries of the Sinos River basin because it showed the biotic degradation in accordance with changes in physical habitat.
\end{abstract}

Keywords: fish fauna, IBI, SCAS index, environmental impact, Sinos River.

\section{A ictiofauna como indicadora da integridade biótica dos arroios da bacia do Rio dos Sinos, Brasil}

\begin{abstract}
Resumo
A bacia do Rio dos Sinos, localizada na região nordeste do Estado do Rio Grande do Sul, Brasil, tem sido altamente impactada devido às atividades industriais e urbanas. A qualidade da água é baixa devido ao escoamento de efluentes domésticos e industriais. A maioria dos tributários sofre drásticas intervenções estruturais, tais como canalizações e remoção de vegetação ciliar. Os objetivos deste estudo foram: 1) avaliar a diversidade de peixes em 34 pontos de vinte e quatro tributários da bacia do Rio dos Sinos; 2) quantificar o nível de impacto através do índice de diversidade de Shannon-Wiener e adaptar um Índice de Integridade Biótica (IBI); e 3) verificar as interferências dos impactos ambientais nas comunidades de peixes, quantificados no Stream Corridor Assessment Survey (SCAS) e 4) comparar a relação entre o IBI com a ordem dos arroios. As amostragens da fauna íctica foram realizadas no período de abril de 2004 a agosto de 2006, utilizando pesca elétrica. Um total de 4.869 indivíduos foi amostrado, representando 61 espécies, 14 famílias e seis ordens. Foram encontradas relações significativas do índice de Shannon-Wiener e do IBI com os escores do SCAS e com a ordem dos arroios. De todos os impactos que compõem o SCAS, somente a alteração do leito foi significativamente correlacionada com o IBI. Estes resultados indicam que a adaptação do IBI foi eficaz e possui um desempenho melhor do que o do índice de diversidade de Shannon-Wiener, quando diretamente relacionado com as categorias de impacto específicas. A aplicação do IBI com o SCAS e as demais variáveis foi eficiente nos afluentes da bacia do Rio dos Sinos, pois mostrou a degradação biótica, em conformidade com as alterações no hábitat físico.
\end{abstract}

Palavras-chave: Ictiofauna, IBI, índice SCAS, impacto ambiental, Rio dos Sinos. 


\section{Introduction}

Aquatic ecosystems have been modified in a significant way due to impacts from human activities. These activities lead to a decrease in water quality and in the diversity of biological communities, due to changing physical and chemical variables (Goulart and Callisto, 2003; Sabater et al., 2000; Tejerina-Garro et al., 2005).

Based on the use of biotic resources as indicators of ecosystem quality, Karr (1981) developed the Index of Biotic Integrity (IBI). The IBI was designed to evaluate the integrity of the fish community of small streams from the temperate climate in the Midwest region of United States. Later it was adapted to the local conditions of many other countries, as for example France (Oberdorff and Porcher, 1994), Lithuania (Kesminas and Virbickas, 2000), Africa (Hocutt et al., 1994; Toham and Teugel,s 1999), New Zealand (Joy and Death, 2004) and Argentina (Hued and Bistoni, 2005). In Brazil, most IBI studies have been carried out in the states of São Paulo and Rio de Janeiro. Araújo (1998), Araújo et al. (2003), Pinto and Araújo (2007), Pinto et al. (2006) developed studies to adapt the index to the Paraíba do Sul river in the state of Rio de Janeiro. Ferreira and Casatti (2006) did the same in the state of São Paulo, and Casatti et al. (2009) in the Upper Paraná River basin. Bozzetti and Schulz (2004) adapted IBI for streams from subtropical climates in the southern region of Brazil. It takes into account differences in the distribution, abundance, and health of the fishes, which are factors linked with the level and type of modification of the water body (Bozzetti and Schulz, 2004). Most IBIs include abundance metrics from faunal elements specific to the area of investigation. The use of these specific metrics impedes the application of a common IBI in different regions of Brazil and decreases the comparability of the results. Additionally, most studies do no quantify environmental impacts as predictor variables for IBI. The specific causes for increase or decrease of IBI scores in different watercourses therefore remain unclear.

Another approach to measure impact levels in aquatic ecosystems is the qualitative and quantitative assessment of physical and chemical impacts (Goulart and Callisto, 2003). Yetman (2001) designed an assessment of environmental impacts on streams based on the Stream Corridor Assessment Survey (SCAS) methodology for the Chesapeake basin in the state of Maryland, USA. This study did not investigate the effects of structural modifications on the fish community. Both methods, IBI and SCAS, are complementary and may be applied together, using SCAS scores as predictors for IBI.

In Rio Grande do Sul, the Sinos River is an example of a heavily impacted, multiple use watercourse, which provides drinking water for 1.6 million inhabitants (Petry and Schulz, 2006). Severe environmental modifications occur in the medium and lower parts of the basin. In these regions, the streams that compose the hydrological network of the basin pass through urban centers with high populations and industrial density (FEPAM, 1999). The main disturbances that degrade the Sinos River tributaries are pollution originating from domestic and industrial sewage in urban areas, eutrophication, erosion and elimination of the riparian buffer strips in agricultural areas. Discharges of toxic industrial sewage occur sporadically, causing fish kills in the river main stem. During the most severe registered fish kill, more than a $100 \mathrm{t}$ died in October 2006 (FEPAM, 2007).

The withdrawal of water for irrigation of rice paddies and drinking water, aquaculture, garbage deposition, and modifications of the physical characteristics of water courses like canalisations are other types of impacts that occur in these streams.

Although the composition of the fish community in the river main stem of the Sinos is well known (Petry and Schulz, 2001), the same is not true for the tributaries. The principal goals of the present study were 1) to assess the diversity of fish at 34 sampling sites in twenty-four tributaries of the Sinos River basin; 2) to quantify impact level by the Shannon-Wiener diversity index and an adapted Index of Biotic Integrity (IBI); 3) to check the interference of environmental impacts, formerly quantified in a Stream Corridor Assessment Survey (SCAS), on the fish assembly and 4) to compare the relationship between the IBI with the order of the streams.

\section{Material and Methods}

\subsection{Study area}

The hydrographic basin of Sinos River is located in the northeastern region of Rio Grande do Sul state, Brazil, with its headwaters in Serra Geral and the river mouth in Canoas near the capital Porto Alegre (Figure 1). The river main stem is $190 \mathrm{~km}$ long and drains an area of approximately $3.820 \mathrm{~km}^{2}$, relative to $1.5 \%$ of the total area of the state (FEPAM, 1999).

The Sinos basin belongs to the phytogeographic region classified as Semidecidual Seasonal Forest (Teixeira et al., 1986), which today only exists on the slopes of the Serra Geral. The climate is subtropical with four well-defined seasons.

The use of water resources is related to soil occupation and to the development of the region. The upper region of the basin, originally covered by forest, is now characterised by plantations of vegetables, sugarcane and rice paddies. In the middle section of the Sinos River basin, large areas are used for rice cultivation and cattle ranching. In the lower region, densely urbanised areas with a high concentration of industries are dominant. Impacts of this area are characterised by water withdrawal for domestic and industrial use, by domestic and industrial sewage as well as huge amounts of domestic garbage (FEPAM, 1999). Only $10 \%$ of domestic sewage is treated. Industrial sewage, although more controlled by environmental defense agencies, occasionally cause severe fish kills, like the one in October 2006, when more than $100 \mathrm{t}$ of fish died. 


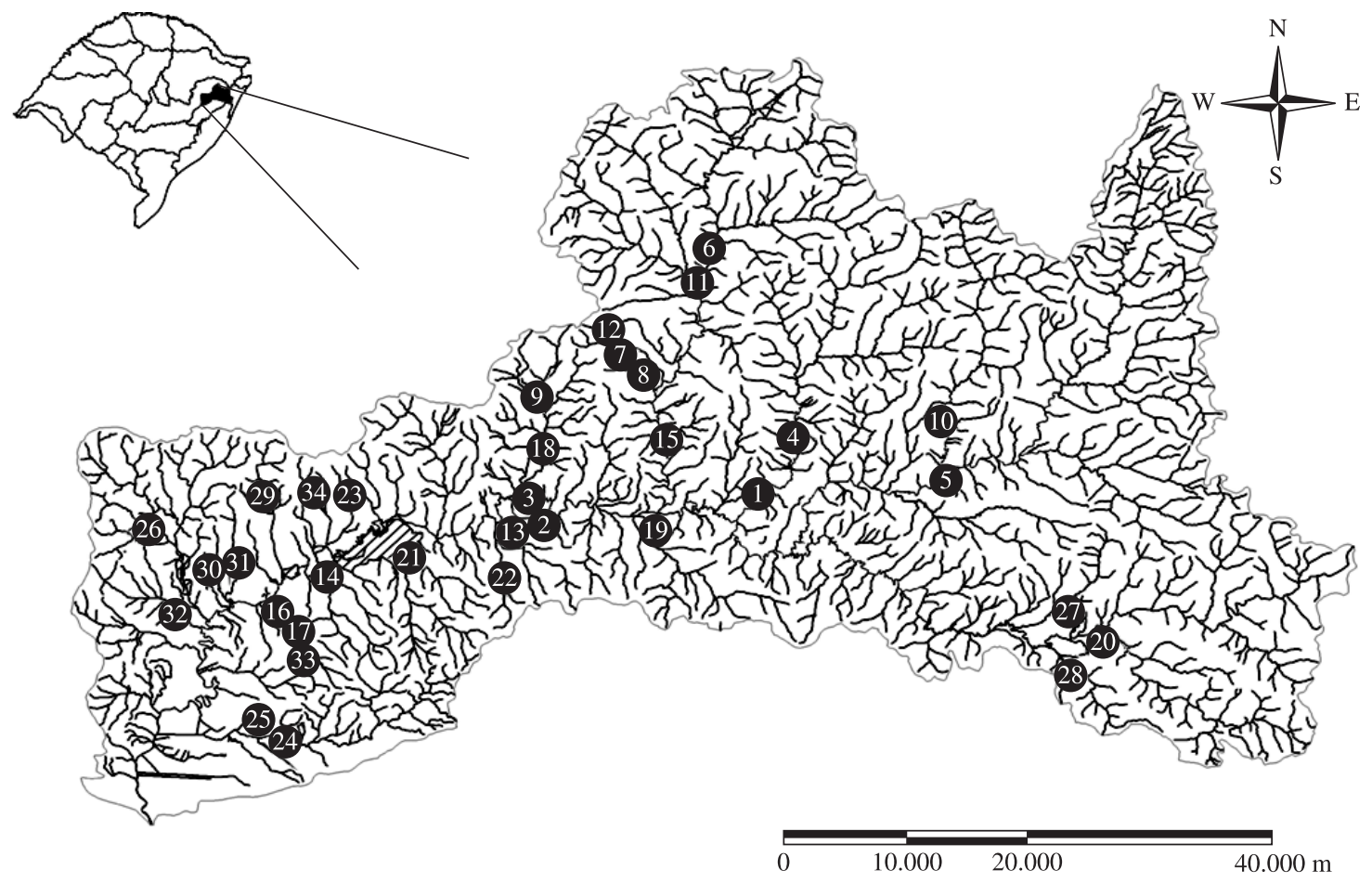

Figure 1. Sampling 34 sites in the Sinos River basin.

The main tributaries of this hydrographic basin are the fifth order rivers Paranhana and Rolante, and of the fourth order river of Ilha. The total extension of the hydrological network is about $4000 \mathrm{~km}$ (Comitesinos, 2008). Wetlands still occur in the lower parts of the drainage basin. The tributaries in the upper region of the basin are characterised by low water temperature, high water velocity, and substrate with variation of size and deposition, forming different microhabitats. The streams located in the medium and lower basin are characterised by low water velocity, high water temperatures, and substrate composed of fine sediment, detritus and low diversity of microhabitats (Bozzetti and Schulz, 2004).

\subsection{Assessment of fish community}

The fish community was analysed at 34 sampling sites distributed in 24 streams, most of them in the lowland region of the basin. Seven streams had more than one sampling site (Figure 1). Sampling was carried between April 2004 and August 2006 by electric fishing, using a $7 \mathrm{~kW}$ generator (model FEG 800 EFKO, Germany) with $750 \mathrm{~V}$ direct current at maximum $3 \mathrm{~A}$, due to low water conductivity (between 25 and $90 \mu \mathrm{S} / \mathrm{cm}$ ). Fishing effort was 40 minutes, which in most cases corresponded to a stretch of 40 times the mean width of the stream (Angermeier and Smogor, 1995). Common fish species were identified on site and released. Others were fixed in formalin $10 \%$ and transferred to ethanol $70 \%$ for posterior processing.

\subsection{Adaptation of IBI}

The IBI suggested by Pinto and Araújo (2007) for Paraíba do Sul River, Rio de Janeiro state, Brazil, was modified for the tributaries of the Sinos River basin. This version of the IBI was more appropriate for lowland streams than the index by Bozetti and Schulz (2004) which was developed for a headwater specific fish fauna. Adaptation of metrics was necessary due to differences in the composition of fish communities found in the two environments (Table 1).

The number of native species was substituted by the total richness, since exotic species were rare $(0.2 \%$ of the total number of individuals). The number of characiform species was substituted by number of individuals in the water column. This alteration allowed the consideration of individuals from other orders of the same habitat use. The number of siluriform species was substituted by the number of benthic species, since the siluriform group comprises species able to breathe atmospheric oxygen and which may occur in high abundances in organically polluted streams (Bozzetti and Schulz, 2004). Therefore, this metric could enhance the index and would exclude benthic individuals from other orders such as Characiformes of the genus Characidium. The metrics suggested by Pinto and Araújo (2007), such as the percentage of Cyprinodontiformes individuals, of omnivores, of carnivores, and the number of dominant species, which represent $90 \%$ of the total 
number of individuals in a sample, were equally applied in the present study.

Parameters such as total richness, number of species in the water column, of benthic species, of sensitive species, number of dominant species and percentage of carnivorous individuals decrease when degradation increases. However, percentage of Cyprinodontiformes and omnivorous individuals are metrics that increase with degradation, due to the adaptation of the individuals to impacted environmental situations.

Since no undisturbed reference sites were available in the basin, the hypothetic reference of Pinto and Araújo (2007) was used. For each parameter, the reference was the best (highest) or worst (lowest) value obtained among all stations, depending on the ecological significance of the metric (Table 2).

A scoring system from one to ten was applied for all parameters. For example, the highest richness was 28 species, hence considered the reference value. This value corresponds to a score of ten. A richness of 16 species received a score $([16 / 28] \times 10)=5.7$. In the cases where the values of the measurements decreased with a pollution increase, (example: species richness) the best (highest) value was used as reference. For metrics that increase with habitat degradation, the worst value was used as reference, for example: $[10-(2.5 / 87.3 \times 10)]=9.71$ where 2.5 is the value of the Cyprinodontiformes percentage of individuals in a stream and 87.3 is the worst of metric value sampled, considered the reference value.
The scores attributed to each metric were added for each site, resulting in a sum with a minimum of zero and a maximum of 80 . Classes were divided in good (scores $\geq 61$ ), moderately impacted ( $\geq 41$ and $\leq 60)$, and impacted (<40), according to Pinto and Araújo (2007).

\subsection{The Stream Corridor Assessment Survey (SCAS)}

Between 2004 and 2006 the Water Committee of the Sinos (Comitesinos) basin organised a SCAS in cooperation with the Universidade do Rio dos Sinos (UNISINOS). SCAS was based on the methodology applied by Yetman (2001) for streams in the Chesapeake basin of the State of Maryland, USA and adapted to local conditions. The survey was carried out by about 200 volunteers from 22 municipalities of the basin. These people were trained to recognise eight impact categories and to attribute severity scores from 1 (small impact) to 3 (severe impact) according to the adapted SCAS manual (Schulz et al., 2004). Volunteers walked along the streams of their municipalities, recorded, photographed and geo-referenced the impacts encountered by GPS. During SCAS a total of 2,000 stream kilometers were assessed and 8,000 field protocols emitted. One of the main products of this study was the cumulative SCAS index, which adds up all impacts encountered in stream segments of five kilometers (Comitesinos, 2009).

The index attributes different weights called impact factors to different impact categories which are multiplied by the severity scores (Table 3). Example: Counted in a five $\mathrm{km}$ segment are: 2 sewage pipes (impact factor 5) of severity 2 and one severity 3 , one erosion (impact factor

Table 1. Metrics of IBI suggested by Pinto and Araújo (2007) and the modifications used in the present study.

\begin{tabular}{ll}
\hline Metrics suggested by Pinto and Araújo (2007) & Metrics used in the river Sinos basin \\
\hline 1. Number of native species & 1. Total richness \\
2. Number of characiform species & 2. Number of species in the water column \\
3. Number of siluriform species & 3. Number of benthic species \\
4. Number of sensitive species & 4. Number of sensitive species \\
5. \% Cyprinodontiformes individuals & $5 . \%$ Cyprinodontiformes individuals \\
6. Number of dominant species & 6. Number of dominant species \\
7. \% omnivorous individuals & 7.\% omnivorous individuals \\
8. \% carnivorous individuals & $8 . \%$ carnivorous individuals \\
\hline
\end{tabular}

Table 2. Criteria to evaluate the Integrity Biotic Index, using as reference the best (highest) or worst (lowest) value obtained among all stations.

\begin{tabular}{lcc}
\hline \multicolumn{1}{c}{ Metrics of IBI } & Best value & Worst value \\
\hline 1. Total richness & 28 & 0 \\
2. Number of species in the water column & 17 & 0 \\
3. Number of benthic species & 10 & 0 \\
4. Number of sensitive species & 15 & 0 \\
5. \% Cyprinodontiform individuals & 0 & 87.3 \\
6. Number of dominant species & 14 & 0 \\
7.\% omnivorous individuals & 0 & 100 \\
8.\% carnivorous individuals & 50 & 0 \\
\hline
\end{tabular}


3) severity 1 and one garbage deposit (impact factor 4) severity 2 . Consequently the index is calculated by $(2 \times 5 \times 2)+(1 \times 5 \times 3)+(1 \times 3 \times 1)+(1 \times 4 \times 2)=56$. For more details check (Schulz et al., 2004).

The impacts present in each section of the streams sampled in this study were obtained by the SCAS realised in the cities between 2004 and 2006. For more details check Schulz et al. (2004).

\subsection{Statistical treatment}

Community diversity was estimated by the ShannonWiener diversity index (H') for each sampling site. Simple linear regressions were performed to verify the possible relationship between IBI and SCAS, IBI and stream orders, SCAS and stream order, Shannon-Wiener and SCAS and finally Shannon-Wiener and stream order. The relationships between environmental variables with IBI and with Shannon-Wiener were analysed using a stepwise multiple regression, to evaluate possible effects of these impacts on the biotic integrity of the streams and in diversity. Statistical analyses were performed using the software SYSTAT (version 12.0, 2007).

\section{Results}

\subsection{Community and fish diversity}

A total of 4,869 fishes were sampled, representing 61 species, distributed in 14 families, belonging to six orders (Table 4). The dominant orders were Siluriformes (40.9\%), Characiformes (37.7\%), and Perciformes $(14.7 \%)$. Families that presented highest richness were Characidae (32.3\%), Loricariidade (16.1\%), and Cichlidae $(14.5 \%)$. The most abundant species were Bryconamericus iheringii (16.5\%), Hyphessobrycon luetkenii (9.9\%), and Gymnogeophagus labiatus (7.1\%). Cichlasoma portalegrense, Heptapterus mustelinus, Hoplosternum littorale, Prochilodus lineatus, and Steindachnerina biornata were recorded only once. Oreochromis niloticus, an exotic species, was sampled in three streams of the basin with a total of 10 individuals (corresponding to $0.2 \%$ of the total number of individuals).

The Shannon-Wiener diversity index varied between $\mathrm{H}^{\prime}=2.59$ in stream number six to $\mathrm{H}^{\prime}=0$ in stream numbers

Table 3. The different weights called impact factors of index attributes for each impact category.

\begin{tabular}{lc}
\hline \multicolumn{1}{c}{ Impact category } & $\begin{array}{c}\text { Impact } \\
\text { factor }\end{array}$ \\
\hline Domestic or industrial sewage pipe & 5.0 \\
Modification of river bed & 4.5 \\
Garbage deposit & 4.0 \\
Inadequate riparian forest & 3.5 \\
Erosion & 3.0 \\
Barrier for fish migration & 2.5 \\
Water withdrawal & 2.0 \\
\hline
\end{tabular}

25, 30 and 34, where fish were absent. Streams with no fish were located exclusively in urban areas. Linear regression between Shannon-Wiener diversity index and stream order showed a positive significant relationship $\left(\mathrm{R}^{2}=0.18 ; \mathrm{P}=0.01 ; \mathrm{N}=34\right)$, (Figure 2).

\subsection{Integrity Biotic Index (IBI)}

All IBI scores fitted in two impact categories: moderately impacted and impacted. Scores higher than 61, characterising good conditions, did not occur. The highest IBI scores were attributed to moderately impacted streams which occurred predominantly in the middle section of the river basin, which is a transition zone between the headwater and floodplain area. The lowest IBI scores occurred in the lower parts of the basin, where urban and industrial areas are concentrated (Table 5).

Linear regression between IBI and SCAS index showed a negative significant relationship (Figure 3), where sites with low SCAS indexes had highest IBIs $\left(\mathrm{R}^{2}=0.25 ; \mathrm{P}=0.004 ; \mathrm{N}=34\right)$. Linear regression between Shannon-Wiener diversity index and SCAS presented a negative significant relationship $\left(\mathrm{R}^{2}=0.52 ; \mathrm{P}=0.002\right.$; $\mathrm{N}=34$ ) (Figure 4). IBI index and order of stream showed a positive significant relationship (Figure 5) $\left(R^{2}=0.43\right.$; $\mathrm{P}=0.01 ; \mathrm{N}=34$ ).

\subsection{Stream Corridor Assessment Survey (SCAS)}

Linear regression between SCAS index and stream order did not show a positive significant relationship $\left(\mathrm{R}^{2}=0.10 ; \mathrm{P}=0.56 ; \mathrm{N}=34\right)$. Multiple linear regression between the scores of the seven impact categories and IBI showed a negative significant relationship only for channel modifications $\left(\mathrm{R}^{2}=0.53 ; \mathrm{P}=0.02 ; \mathrm{N}=34\right)$. The same relationship was apparent between channel modification and Shannon-Wiener index, but explaining a lesser degree of variance $\left(\mathrm{R}^{2}=0.45 ; \mathrm{P}=0.02 ; \mathrm{N}=34\right)$.

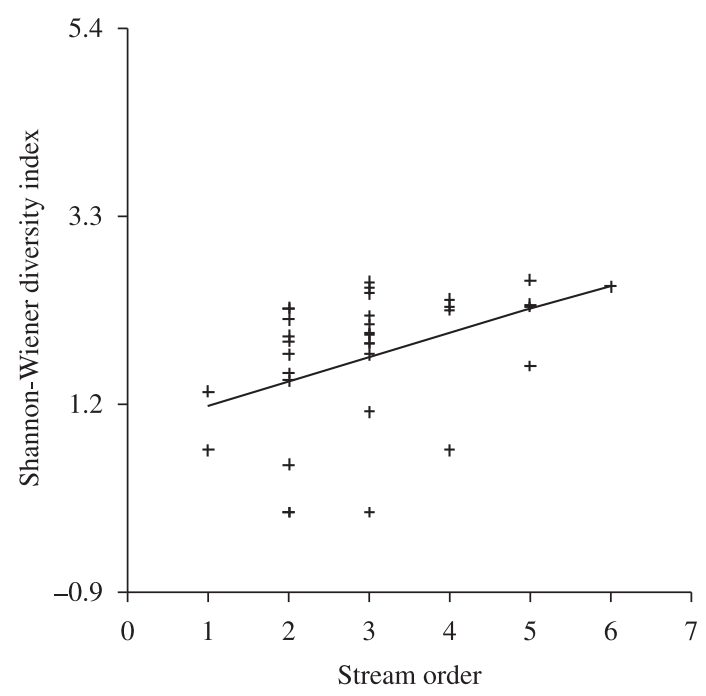

Figure 2. Linear regression between the diversity index of Shannon-Wiener and the stream order for 34 streams in the Sinos River basin. 
Table 4. Abundance and classification of fish species according to the order, family, total abundance, longevity, trophic level, tolerance to disturbances and habit in the water column. $\mathrm{c}=$ carnivore, $\mathrm{h}=$ herbivore, $\mathrm{i}=$ insectivore, $\mathrm{o}=$ omnivore; in $=$ intolerant, $\mathrm{t}=$ tolerant; $\mathrm{b}=$ benthonic, $\mathrm{ba}=$ benthonic able to breathe atmospheric $\mathrm{O}_{2}, \mathrm{wc}=$ water column and $\mathrm{s}=$ surface.

\begin{tabular}{|c|c|c|c|c|}
\hline Species & $\begin{array}{c}\text { Total } \\
\text { abundance }\end{array}$ & Trophic level & Tolerance * & $\begin{array}{c}\text { Habit in water } \\
\text { column }\end{array}$ \\
\hline \multicolumn{5}{|l|}{ Characiformes } \\
\hline \multicolumn{5}{|l|}{ Characidae } \\
\hline Astyanax alburnus & 27 & o & in & wc \\
\hline Astyanax fasciatus & 37 & o & $\mathrm{T}$ & wc \\
\hline Astyanax jacuhiensis & 148 & o & $\mathrm{T}$ & wc \\
\hline Astyanax scabripinnis & 130 & o & in & $\mathrm{wc}$ \\
\hline Astyanax henseli & 201 & o & in & wc \\
\hline Astyanax sp. & 57 & o & in & wc \\
\hline Bryconamericus iheringii & 808 & o & in & $\mathrm{wc}$ \\
\hline Characidium orientale & 19 & $\mathrm{i}$ & in & $\mathrm{b}$ \\
\hline Characidium pterostictum & 294 & $\mathrm{i}$ & in & $\mathrm{b}$ \\
\hline Characidium tenue & 4 & $\mathrm{i}$ & $\mathrm{T}$ & wc \\
\hline Characidium zebra & 27 & $\mathrm{i}$ & in & wc \\
\hline Cheirodon ibicuhiensis & 79 & o & in & wc \\
\hline Diapoma speculiferum & 11 & o & in & wc \\
\hline Hyphessobrycon bifasciatus & 3 & o & in & wc \\
\hline Hyphessobrycon boulengeri & 3 & o & in & $\mathrm{wc}$ \\
\hline Hyphessobrycon luetkenii & 480 & o & $\mathrm{T}$ & $\mathrm{wc}$ \\
\hline Mimagoniates inequalis & 46 & $\mathrm{i}$ & in & $\mathrm{s}$ \\
\hline Oligosarcus robustus & 14 & $\mathrm{c}$ & in & $\mathrm{wc}$ \\
\hline Pseudocorynopoma doriae & 56 & o & in & $\mathrm{s}$ \\
\hline \multicolumn{5}{|l|}{ Curimatidae } \\
\hline Cyphocharax voga & 14 & o & in & wc \\
\hline Steindachnerina biornata & 1 & o & in & $\mathrm{wc}$ \\
\hline \multicolumn{5}{|l|}{ Erythrinidae } \\
\hline Hoplias malabaricus & 38 & $\mathrm{c}$ & $\mathrm{T}$ & $\mathrm{wc}$ \\
\hline \multicolumn{5}{|l|}{ Prochilodontidae } \\
\hline Prochilodus lineatus & 1 & $\mathrm{o}$ & $\mathrm{T}$ & $\mathrm{b}$ \\
\hline \multicolumn{5}{|l|}{ Cyprinodontiformes } \\
\hline \multicolumn{5}{|l|}{ Poeciliidae } \\
\hline Phalloceros caudimaculatus & 233 & o & $\mathrm{T}$ & $\mathrm{s}$ \\
\hline \multicolumn{5}{|l|}{ Gymnotiformes } \\
\hline \multicolumn{5}{|l|}{ Gymnotidae } \\
\hline Gymnotus carapo & 45 & o & in & $\mathrm{wc}$ \\
\hline \multicolumn{5}{|l|}{ Sternopygiidae } \\
\hline Eigenmannia virescens & 5 & $\mathrm{i}$ & in & $\mathrm{wc}$ \\
\hline \multicolumn{5}{|l|}{ Perciformes } \\
\hline \multicolumn{5}{|l|}{ Cichlidae } \\
\hline Australoherus facetus & 22 & o & $\mathrm{T}$ & wc \\
\hline Cichlasoma portalegrense & 1 & o & $\mathrm{T}$ & wc \\
\hline Crenicichla lepidota & 27 & $\mathrm{c}$ & in & wc \\
\hline
\end{tabular}

* Bozzetti and Schulz (2004) 
Table 4. Continued...

\begin{tabular}{lcccc}
\hline \multicolumn{1}{c}{ Species } & $\begin{array}{c}\text { Total } \\
\text { abundance }\end{array}$ & Trophic level & Tolerance * & $\begin{array}{c}\text { Habit in water } \\
\text { column }\end{array}$ \\
\hline Crenicichla punctata & 129 & $\mathrm{c}$ & $\mathrm{in}$ & $\mathrm{wc}$ \\
Geophagus brasiliensis & 52 & $\mathrm{o}$ & $\mathrm{T}$ & $\mathrm{wc}$ \\
Gymnogeophagus gymnogenys & 220 & $\mathrm{o}$ & $\mathrm{T}$ & $\mathrm{wc}$ \\
Gymnogeophagus labiatus & 348 & $\mathrm{o}$ & $\mathrm{in}$ & $\mathrm{wc}$ \\
Gymnogeophagus rhabdotus & 70 & $\mathrm{o}$ & $\mathrm{T}$ & $\mathrm{wc}$ \\
Oreochromis niloticus & 10 & $\mathrm{o}$ & $\mathrm{wc}$
\end{tabular}

Siluriformes

Callichthyidae

Callichthys callichthys

Corydoras paleatus

Corydoras undulates

Hoplosternum littorale

Loricariidae

Ancistrus brevipinnis

Hemiancistrus punctulatus

Hisonotus nigricauda

Hisonotus sp.

Hypostomus commersoni

Loricariichthys anus

3

Otocinclus flexilis

Rineloricaria cadeae

Rineloricaria microlepidogaster

Rineloricaria sp.

Heptapteridae

Heptapterus mustelinus

Heptapterus sympterygium

Pimelodella australis

Rhamdella eriarcha

Rhamdia quelen

$\begin{array}{lll}\mathrm{o} & \mathrm{T} & \mathrm{ba} \\ \mathrm{o} & \mathrm{T} & \mathrm{ba} \\ \mathrm{o} & \mathrm{T} & \mathrm{ba} \\ \mathrm{o} & \mathrm{T} & \mathrm{ba}\end{array}$

Pseudopimelodidae

Microglanis cottoides

Pimelodidae

Parapimelodus nigribarbis

Tricomycteridae

Scleronema minutum

Trichomycterus sp. 1

Trichomycterus sp. 2

Trichomycterus sp. 3

o $\mathrm{T}$ ba

o

Synbranchiformes

Synbranchidae

* Bozzetti and Schulz (2004) 
Table 5. Identification of streams moderately impacted and impacted conditions resulting from the application of Biotic Integrity Index. $\mathrm{H}=$ Headwaters, $\mathrm{M}=$ Middle and $\mathrm{L}=$ Lower section.

\begin{tabular}{|c|c|c|c|c|c|c|c|c|c|}
\hline \multicolumn{10}{|c|}{ Moderately impacted } \\
\hline Stream & 19 & 18 & 13 & 7 & 9 & 4 & 20 & 6 & 5 \\
\hline Value IBI & 54.7 & 52.7 & 52.7 & 50.7 & 49.8 & 48.5 & 46.1 & 46.0 & 45.2 \\
\hline Section & $\mathrm{M}$ & $\mathrm{M}$ & M & M & $\mathrm{M}$ & $\mathrm{H}$ & $\mathrm{M}$ & M & M \\
\hline \multicolumn{10}{|c|}{ Impacted } \\
\hline Stream & 10 & 1 & 12 & 21 & 28 & 14 & 3 & 24 & 11 \\
\hline Value IBI & 39.0 & 38.2 & 37.4 & 35.5 & 33.8 & 33.7 & 33.7 & 32.8 & 32.4 \\
\hline Section & $\mathrm{M}$ & $\mathrm{M}$ & M & $\mathrm{L}$ & $\mathrm{H}$ & $\mathrm{L}$ & $\mathrm{M}$ & $\mathrm{L}$ & M \\
\hline Stream & 17 & 33 & 27 & 16 & 26 & 2 & 8 & 31 & 22 \\
\hline Value IBI & 31.9 & 31.1 & 30.4 & 30.3 & 28.4 & 27.8 & 27.5 & 25.3 & 24.3 \\
\hline Section & $\mathrm{L}$ & $\mathrm{L}$ & $\mathrm{H}$ & $\mathrm{L}$ & $\mathrm{L}$ & $\mathrm{L}$ & $\mathrm{M}$ & $\mathrm{L}$ & $\mathrm{L}$ \\
\hline Stream & 15 & 23 & 29 & 32 & 25 & 30 & 34 & & \\
\hline Value IBI & 23.6 & 18.4 & 17.6 & 12.1 & 11.7 & 11.7 & 0.0 & & \\
\hline Section & $\mathrm{M}$ & $\mathrm{L}$ & $\mathrm{L}$ & $\mathrm{L}$ & $\mathrm{L}$ & $\mathrm{L}$ & $\mathrm{L}$ & & \\
\hline
\end{tabular}

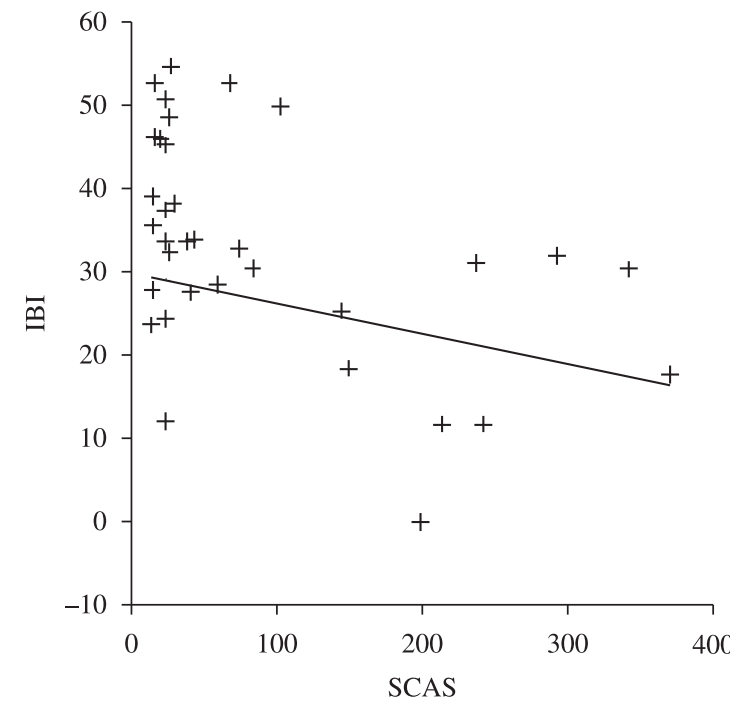

Figure 3. Linear regression between IBI and SCAS index for 34 streams in the Sinos River basin.

\section{Discussion}

The fish community represented by 61 species was similar to that of a study in the main stem of the Sinos River, where 68 species were recorded (Petry and Schulz, 2006), demonstrating that the diversity of the Sinos River is well represented in the tributaries.

The predominance of Characiforms and Siluriforms in streams of the basin of Sinos River, followed the pattern observed in other Brazilian systems (Ferreira and Petrere Jr., 2007; Smith et al., 2003; Suarez et al., 2004; Teixeira et al., 2004, 2005).

Nine of the 34 sampling sites were considered moderately impacted and 25 impacted. No sampling site achieved an IBI score higher than 61 which was the lower score limit for good conditions. The absence of this highest IBI

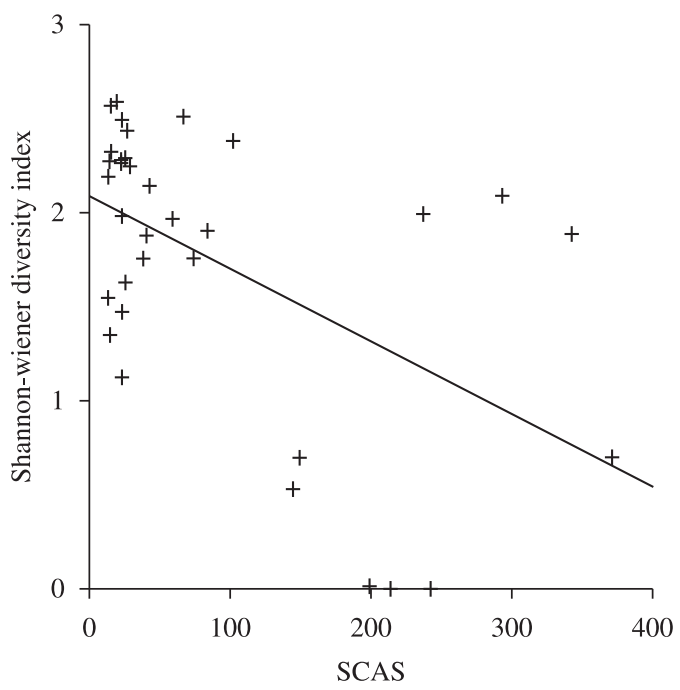

Figure 4. Linear regression between Shannon-Wiener Diversity Index and SCAS Index for 34 streams in the Sinos River basin.

category demonstrates the general impact level in the river basin. Virtually all streams in the densely urbanised and industrialised catchment area of the Sinos River suffer at least moderate impacts. Almost pristine and undisturbed watercourses probably still exist, but they are located on the slopes of the Serra Geral, a steep gradient and densely forested area of difficult access, which was not part of the study. Two out of three headwater sites were categorised as impacted, showing an ongoing degradation process even in formerly less disturbed areas. In the study by Bozetti and Schulz (2004), streams 28 and 27 were considered moderately impacted. In the present study both streams were considered impacted.

The relationship of the IBI and of the sites with low SCAS scores (=fewer environmental impacts) is relatively 


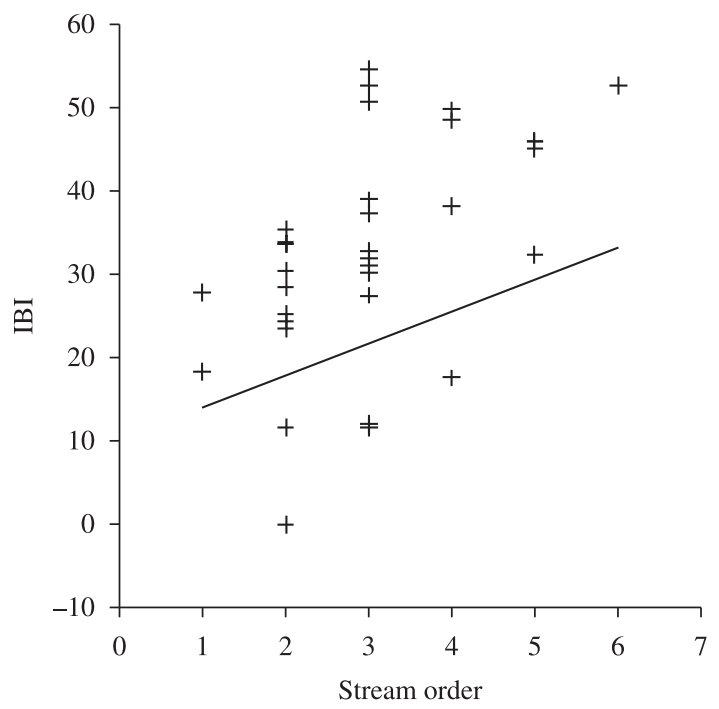

Figure 5. Linear regression between IBI and stream order for 34 streams in the Sinos River basin.

low and explains only $25 \%$ of the variance. Since the SCAS sores are composed of eight impact parameters, it was important to identify the impact category which contributed most to IBI reduction. Multiple regression showed that channel modifications were the most important predictor variable, explaining $53 \%$ of the variance in reduction of IBI scores. The number of sewage pipes which are indicators of organic and chemical water pollution and other impact categories that compose the SCAS index did not contribute significantly to the model. According to the results of this study, the decrease of IBI scores in urban areas is principally caused by physical degradation of the aquatic environment. Apparently, canalisation and the inherent homogenisation of microhabitats influence IBI scores more negatively than the decrease in water quality. The Shannon-Wiener diversity index responded as well negatively to canalisation but less apparent.

Ferreira and Casatti (2006) observed in a Brazilian stream that structural variables like absence of riparian vegetation, low substrate stability and low water depth, influence biotic integrity more than water quality. Canalised river segments with homogeneous substrate, low water depth and low habitat complexity had a lesser diversity and abundance fish community than undisturbed river stretches (Fausch and Bramblett, 1991; Paller, 2002).

We found correlations between the increase in biotic integrity and diversity with stream order, reflecting the predictive power of this descriptor. Casatti et al. (2006), Braga and Andrade (2005) and Goldstein and Meador (2004) also reported an increase in the number of species per stream order. This relationship of species richness and stream order is considered to be a result of the species area relationship (Angermeier and Schlosser, 1989). Larger streams with higher water discharge sustain a higher diversity of habitats and allow the coexistence of more species with very different biological characteristics: Species of the genus Astyanax, occupying the water column and feeding on drifting particles, Gymnotus using the riverbanks for shelter and feeding and Hypostomus which occurs on rocky substrate in fast flowing river stretches (Ferreira and Casatti, 2006). Fish assemblages in the streams with the lowest IBI values were composed of Synbranchus marmoratus, Corydoras paleatus and Otocinclus flexillis. These are extremely tolerant species and are the last to disappear in response do environmental degradation (Bozetti and Schulz, 2004). Of these $S$. marmoratus seems to be the last to die or disappear in poorly oxygenated water bodies.

These results indicated that the adaptation of the IBI applying as reference the best (highest) or worst (lowest) value obtained among all stations was effective and can be tested in studies in other regions. The application of the IBI with the SCAS index showed that structural modifications of stream habitat had the most important effect on the IBI. The combination of IBI with quantitative assessments of structural and chemical impacts, as showed in the present study, offers a relatively low cost method for environmental assessment with a rapid return of results. The use of our IBI indicated that this index could be applied in different regions of Brazil, since it is composed by metrics that include functional groups. The only exception as functional groups, is the metric of the presence or absence of Cyprinodontiformes, which is used in tropical regions of the Americas, Asia and Africa (Jaramillo-Villa and Caramaschi, 2005). This metric contains representative indicators of degraded sites, such as species of the family Poeciliidae (Araújo, 1998) and preserved environments, such as native species of Cyprinodontidae (Toham and Teugels, 1999). Cyprinodontiformes is a group widely distributed in Brazil and may be IBI included in studies throughout the country.

These results show that application of the IBI could be an important tool for biomonitoring, when used in addition to other indices, since it infers the quality of environmental prediction using different levels of fish community organization.

Acknowledgements - We would like to thank the interns of the Fish Ecology Laboratory of the Universidade do Vale do Rio dos Sinos - UNISINOS - for their help in the development of this work and the group in the Fish Laboratory of the Pontifícia Universidade Católica do RGS - PUCRS - for the identification of some specimens. The SCAS was funded by the Secretary of Hydrological Recourses (SRH) of the state of Rio Grande do Sul.

\section{References}

ANGERMEIER, PL. and SCHLOSSER, IJ., 1989. Speciesarea relationships for stream fishes. Ecology, vol. 70, no. 5, p. 1450-1462.

ANGERMEIER, PL. and SMOGOR, RA., 1995. Estimating number of species and relative abundances in stream-fish communities: effects of sampling effort and discontinuous spatial distributions. Canadian Journal of Fisheries and Aquatic Sciences, vol. 52, p. 936-949. 
ARAÚJO, FG., 1998. Adaptação do índice de integridade biótica usando a comunidade de peixes para o Rio Paraíba do Sul. Revista Brasileira de Biologia = Brazilian Journal of Biology, vol. 58, no. 4, p. 4547-558.

ARAÚJO, FG., FICHBERG, I., PINTO, BCT. and PEIXOTO, MG., 2003. A preliminary index of biotic integrity for monitoring the condition of the Rio Paraíba do Sul, Southeast Brazil. Environmental Management, vol. 32, no. 4, p. 516-526.

BOZZETTI, M. and SCHULZ, UH., 2004. An index of biotic integrity based on fish assemblages for subtropical streams in southern Brazil. Hydrobiologia, vol. 529, p. 133-144.

BRAGA, FMS. and ANDRADE, PM., 2005. Distribuição de peixes na microbacia do Ribeirão Grande, Serra da Mantiqueira Oriental, São Paulo, Brasil. Iheringia, Série Zoologia, vol. 95, p. 121-126.

CASATTI, L., FERREIRA, CP. and LANGEANI, F., 2009. A fish-based biotic integrity index for assessment of lowland streams in southeastern Brazil. Hydrobiologia, vol. 623, no. 1, p. $173-189$.

CASATTI, L., LANGEANI, F. and FERREIRA, CP., 2006. Effects of physical habitat degradation on the stream fish assemblage structure in a pasture region. Environmental Management, vol. 38, p. 974-982.

Comitê de Gerenciamento da Bacia Hidrográfica do Rio dos Sinos - COMITESINOS, 2008. Available from: <http://www. comitesinos.com.br/site>. Access in: 04 Nov. 2009.

-, 2009. Available from: <http://www.comitesinos.com.br>. Access in: 05 Dec. 2009.

FAUSCH, KD. and BRAMBLETT, RG. 1991. Disturbance and fish communities in intermittent tributaries of a western Great Plains river. Copeia, vol. 199, p. 659-674.

FERREIRA, FC. and CASATTI, L., 2006. Integridade biótica de um córrego na bacia do Alto Rio Paraná avaliada por meio da comunidade de peixes. Biota Neotropica, vol. 6, no. 3. Available from: <http://www.biotaneotropica.org.br/v6n3/pt/abstract?artic le+bn00306032006>.

FERREIRA, FC. and PETRERE-JUNIOR, M., 2007. Anthropic effects on the fish community of Ribeirão Claro, Rio Claro, SP, Brazil. Brazilian Journal of Biology, vol. 1, p. 23-32.

Fundação Estadual de Proteção Ambiental Henrique Luis Roessler - FEPAM., 1999. Qualidade das águas do Rio dos Sinos: monitoramento da qualidade de água. Porto Alegre, $49 \mathrm{p}$.

-, 2007. Eventos de mortandade de peixes - Rio dos Sinos. Porto Alegre, $185 \mathrm{p}$.

GOLDSTEIN, RM. and MEADOR, MR., 2004. Comparisons of fish species traits from small streams to large rivers. Transactions of the American Fisheries Society, vol. 133, p. 971-983.

GOULART, M. and CALLISTO, M., 2003. Bioindicadores de qualidade de água como ferramenta em estudos de impacto ambiental. Revista FAPAM, vol. 2, p. 152-164.

HOCUTT, CH., JOHNSON, PN., HAY, C. and VAN-ZYL, BJ., 1994. Biological basis of water quality assessment: the Kavango River, Namibia. Revue Hydrobiologique Tropicale, vol. 27, p. 361-384.

HUED, AC. and BISTONI, MDA., 2005. Development and validation of a biotic index for evaluation of environmental quality in the central region of Argentina. Hydrobiologia, vol. 543, p. $279-298$

JARAMILLO-VILLA, U. and CARAMASCHI, EP., 2008. Índices de integridade biótica usando peixes de água doce: Uso nas regiões tropical e subtropical. Oecologia Brasiliensis, vol. 12, no. 3 , p. $442-462$.

JOY, MK. and DEATH, RG., 2004. Application of the index of biotic integrity methodology to New Zealand freshwater fish communities. Environmental Management, vol. 34, no. 3, p. $415-428$.

KARR, JR., 1981. Assessment of biotic integrity using fish communities. Fisheries, vol. 6, p. 21-27.

KESMINAS, V. and VIRBICKAS, T., 2000, Application of an adapted index of biotic integrity to rivers of Lithuania. Hydrobiologia, vol. 422/423, p. 257-270.

OBERDORFF, T. and PORCHER, JP., 1994. An index of biotic integrity to assess biological impacts of salmonids farm effluents on receiving waters. Aquaculture, vol. 119, p. 219-235.

PALLER, MH., 2002. Temporal variability in fish assemblages from disturbed and undisturbed streams. Journal of Aquatic Ecosystems Stress and Recovery, vol. 9, p. 149-158.

PETRY, AC. and SCHULZ, UH., 2001. Levantamento da comunidade de peixes do Rio dos Sinos, RS. Acta Biologica Leopoldensia, vol. 23, no. 1, p. 49-58.

PETRY, AC. and SCHULZ, UH., 2006. Longitudinal changes and indicator species of the fish fauna in the subtropical Sinos River, Brazil. Journal of Fish Biology, vol. 69, p. 272-290.

PINTO, BCT and ARAÚJO, FG., 2007. Assessing of biotic integrity of the fish community in a heavily impacted segment of a Tropical River in Brazil. Brazilian Archives of Biology and Technology, vol. 3, p. 489-502.

PINTO, BCT., ARAÚJO, FG. and HUGHES, RM., 2006 Effects of landscape and riparian condition on a fish index of biotic integrity in a large southeastern Brazil river. Hydrobiologia, vol. 556, p. 69-83.

SABATER, FB., EUGENIA, M., ISABEL, M., ANNA, R., JOANNE, W. and SERGI, S., 2000. Effects of riparian vegetation removal on nutrient retention in a Mediterranean stream. Journal of the North American Benthological Society, vol. 19, p. 609-620.

SCHULZ, UH., NABINGER, V., GOMES, LP., LORENZI, MR. and COSTA, PF., 2004. MONALISA: Monitoramento das Alterações das Ambientais em Arroios: Manual de Campo. São Leopoldo, RS: Comitê de Gerenciamento da Bacia Hidrográfica do Rio dos Sinos - COMITESINOS, 16 p. Available from: <http:// www.comitesinos.com.br>.

SMITH, WS., PETRERE-JUNIOR, M. and BARRELLA, W., 2003. The fish fauna in tropical rivers: The case of the Sorocaba river basin, SP, Brazil. Revista de Biologia Tropical, vol. 3, p. $769-782$

SÚAREZ, YR., PETRERE-JÚNIOR, M. and CATELLA, AC., 2004. Factors regulating diversity and abundance of fish communities in Pantanal lagoons, Brazil. Fisheries Management Ecology, vol. 11 , p. $45-50$.

TEIXEIRA, MB., COURA NETO, AB., PASTORE, U. and RANGEL-FILHO, ALR., 1986. Vegetação. In RADAMBRASIL. Levantamento de recursos naturais. Rio de Janeiro: IBGE, vol. 33, p. 541-620. 
TEIXEIRA, TP., PINTO, BCT., TERRA, BF., ESTILIANO, EO., GARCIA, D. and ARAÚJO, FG., 2005. Diversidade das assembléias de peixes nas quatro unidades geográficas do rio Paraíba do Sul. Iheringia Série Zoologia, vol. 4, p. 347-357.

TEIXEIRA, TP., TERRA, BF., ESTILIANO, EO., GRACIA, D., PINTO, BCT. and ARAÚJO, FG., 2004. Distribuição da ictiofauna em locais impactados no Rio Paraíba do Sul. Revista da Universidade Rural, Série Ciência e Vida, vol. 2, p. 167-174

TEJERINA-GARRO, FL., MALDONADO, M., IBAÑEZ, C., PONT, D., ROSET, N. and OBERDORFF, T., 2005. Effects of natural and anthropogenic environmental changes on riverine fish assemblages: a framework for ecological assessment of rivers. Brazilian Archives of Biology and Technology, vol. 48, p. 91-108.

TOHAM, AK. and TEUGELS, GG., 1999. First data of an index of biotic integrity (IBI) based on fish assemblage for the assessment of the impact of deforestation in a tropical wet African river system. Hydrobiologia, vol. 397, p. 29-38.

YETMAN, KT. (Org.), 2001. Stream Corridor Assessment Survey - Survey Protocols. Annapolis, MD: Watershed Restoration Division Chesapeake and Coastal Watershed Services, Department of Natural Resources, 68 p. 